\title{
SOCIO-PHILOSOPHICAL ANALYSIS OF LIFESTYLE IN THE CONTEXT OF ETHNOCULTURAL TRADITIONS
}

\author{
(C) Vyacheslav A. Berkovskiy, Larisa A. Tronina, Aleksander A. Volkov
}

\author{
Stavropol State Pedagogical University, \\ North-Caucasus Federal University, Stavropol, Russian Federation \\ science-almanac@mail.ru
}

\begin{abstract}
Lifestyle is a historical category that characterizes the real functioning life activities of people in the past, present and future. The way of life includes all forms of life activities of people, individuals, groups, societies. Currently, the concept of lifestyle is designed to reflect the degree of development of this society, the dynamics of living standards, and the harmonious development of the individual most comprehensively. The way of life of the vast majority of modern families is determined by the employment of spouses in public production. Various types of lifestyle development in the context of ethnocultural traditions are analyzed. Possible ways of using ethnocultural traditions of labour education and improving the domestic sphere of lifestyle of the modern family have been identified. It has been shown that for the vast majority of families, the problems caused by the well-known double industrial and family activities are relevant. One of the important problems in this aspect solved on a state scale is the improvement of the level of development and further specialization of the public service sector, the purpose of which is to meet the growing demands of the population in various forms of service, facilitate work, create better recreational conditions. However, although as a result of this important social objective, activities in the family may be minimized, the uneven burden in the domestic sphere may persist until the rational distribution of work among all family members becomes the norm of intra-family relations.
\end{abstract} traditions.

Key words: education, value orientations, socialization, culture, ethnos, social policy, ethnocultural

\section{[В.А. Берковский, Л.А. Тронина, А.А. Волков Социально-фрилософский анализ образа жизни в контексте этнокультурных традиций]}

Образ жизни - категория историческая, характеризующая реально фуункционирующую жизнедеятельность людей в прошлом, настоящем и будущем. Образ жизни включает в себя все формы жизнедеятельности людей - личности, группы, общества. В настоящее время понятие образ жизни призвано наиболее всесторонне отразить степень развития данного общества, динамику уровня жизни, гармоничное развитие личности. Образ жизни подавляющего большинства современных семей определяется занятостью супругов в общественном производстве. Проанализированы различные типы развития образа жизни в контексте этнокультурных традиций. Выделены возможные пути использования этнокультурных традиций трудового воспитания и совершенствовании бытовой сферы образа жизни современной семьи. Показано, что для подавляющего большинства семей актуальны проблемы, порожденные широко известной двойной - производственной и семейной деятельностью. Одна из важных проблем в этом аспекте решаемая в государственном масштабе, - повышение уровня развития и дальнейшая специализация общественной сферы услуг, назначение которой - удовлетворить растущие запросы населения в разнообразных формах обслуживания, облегчить трудовую деятельность, создать лучшие условия для отдыха. Однако до какого минимума ни сводилась бы деятельность в семье благодаря реализации этой важной социальной задачи, неравномерная нагрузка в бытовой сфере может сохраняться до тех пор, пока нормой внутрисемейных отношений не станет рациональное распределение работы между всеми членами семьи.

Ключевые слова: воспитание, ценностные ориентации, социализация, культура, этнос, социальная политика, этнокультурные традиции.

Vyacheslav A. Berkovskiy - Ph.D. in Sociology, Associate Professor, Stavropol State Pedagogical Institute, Stavropol, Russian Federation.

Larisa A. Tronina - Ph.D. (Advanced Doctorate) in Philosophy, Associate Professor, Stavropol State Pedagogical Institute, Stavropol, Russian Federation. 
Aleksander A. Volkov - Ph.D. (Advanced Doctorate) in Psychology, Professor, North Caucasus Federal University, Stavropol, Russian Federation.

Берковский Вячеслав Александрович - кандидат социологических наук, доцент, Ставропольский государственный педагогический институт, г. Ставрополь, Российская Федерация.

Тронина Лариса Анатольевна - доктор философьских наук, доцент, Ставропольский государственный педагогический институт, г. Ставрополь, Российская Федерация.

Волков Александр Александрович - доктор психологических наук, профрессор, Северо-Кавказский федеральный университет, г. Ставрополь, Российская Федерация.

Labour education of children in the family should be given great attention. In the process of raising children, providing... "promoting positive attitudes towards cultural differences" [2, pp. 7-10], in which the family, the educational institution, the public, social groups and institutions participate, the task of the family is to raise children in the spirit of respect and love for work, prepare them for socially useful activities. This task is set taking into account the continuing primary role of the family in the formation of children's moral concepts, value orientations, attitudes, and first labour skills. In modern living conditions, the participation of children in the working life of the family is limited mainly to the household sphere.

In each particular historical era, the role of the family in labour education of children was determined by certain socio-economic, ethnocultural, environmental and other factors. The realization by the family of this one of the most important functions of socialization is not regulated in many ways, and therefore the labour education of children in each particular case occurs depending on the whole way of life of the family, including labour activity of parents and their attitude to it, the objective need for children to participate in work and many other circumstances. Ethnocultural traditions of labour education of a people play an important role in this.

Among different peoples, these traditions historically developed in the conditions of functioning of the family as a relatively closed economic unit even in the era of feudalism. The way of life was inextricably linked to the process of production of means of life, and the transfer of labour skills from adults to children took place directly during this process.

Traditions of attitude to labour are reflected in oral folk arts. Labour as the main criterion of human value was praised in its most common genre, in folk songs. In folk songs, the concepts of working and living are often used as synonyms. The concepts of beauty, virtue, nobility and many others were often perceived through the assessment of labour.

This also applies to such a genre of oral folk arts as children's folklore. In lullaby songs, underlying theme reflects thoughts and aspirations of mother for the future of her child. It was vital for peasant children as they grew older to learn to plow, sow, mow, care for livestock and do all the other household works. The conditions for farming in the feudal period, when the traditions of labour education that had survived to this day were mainly formed, required the participation of all family members in it.

Work that was associated with a lot of physical activity was traditionally carried out by men, and women were busy with housekeeping, participated in mowing, harvesting, and cared for cattle. However, the shortage of workers in the peasant household, where a family consisting of parents with children dominated, led to the fact that women often shared all the hard work with men. It was this circumstance that determined the requirements for raising children who were included in the working life of the family after reaching a certain age and physical maturity, and often did hard work even if they did not reach this maturity. The participation of children in work in the peasant household was dictated by objective necessity. However, it was not a specifically Baltic social phenomenon, which determines "the need to consider... dispositions of social structures" [1, pp. 168-177]. 
The constant educational factor for peasant children was the whole way of the family's life. Parents were deeply interested in the results of upbringing, since only hard work could to some extent guarantee the elementary conditions of existence and give hope for improving life in the future.

These trends persist in the traditions of labour education of children. That makes it possible to affirm an ethnic and sociological survey of nuclear families with school-age children. The survey was conducted in single-national and national-mixed rural and urban families. In each family, three people were interviewed, the husband, the wife, and the eldest of school-age children. The survey was conducted by means of a questionnaire developed taking into account previous studies in various regions, in particular studies of the family and cultural activities in the family. Particular importance was attached to the experience of research of cultural activities within the family and the transfer of culture. Parameters of social and demographic characteristics, blocks of questions about the consumption of professional culture in the family, as well as a number of indicators of intrafamily relations, attitudes and value orientations that are determined..." by the forms of spiritual and practical development of the world, and express a person's value attitude to the reality" were recorded [4, pp. 9-12]. Religious beliefs are also relevant, "the influence of Orthodoxy on the formation and processing of Russian culture" [8, pp. 39-44].

Typologically another entity is the cultural foundation of modern ethnic groups. The important feature of its development is the fact that at the same time not only new material and spiritual values are developing, but there is the development of cultural heritage increasingly. Life presents a lot of evidence that it is impossible without serious consequences to limit the effect of the principle: history belongs to the people. The return to modern ethnic groups of their past takes place in various ways. Ethnography has significant scientific opportunities for reconstruction of lost fragments and entire types of culture and creation of certain cognitive prerequisites for their return to the fund of culture of the people. In modern conditions, science and professional art act as the most powerful channels for creating secondary (in the ethnographic sense of the word) layers of folk culture.

We can safely assume that here we have a significant feature of the development of cultural foundation of the ethnic group. A certain phenomenon of culture, which goes through its time and acquires features of ethnocultural experience of the people, continues its existence as an aesthetic phenomenon with pronounced ethnic marking.

The man began spiritual mastery of reality with a holistic reflection of the externalnatural and his own bodily-natural world. The mythological creativity of the peoples of all continents confirmed this clearly. Thus, the early types of ethnic consciousness can be described as artistic in form and covering the world in content. The views of the world of ethnic groups contain both general and specific features. Ethnography has wide material that makes it possible to judge the degree of diversity and the degree of commonality of ideas about the world of various ethnic groups reasonably. Thus, science solves the fundamental problem of studying the historical and cultural prerequisites of ideology and practice of social consciousness.

The scope of the category of ethnic identity is world-wide and, in this sense, it is identical to the concept of the ethnic picture of the world. But there is a difference between them. The first is born of the need to reflect the dynamics of ethnic processes, subjective moments of ethno-contact relations. The second is more applicable when it is necessary to emphasize the objective nature of some historical form of ethnic consciousness, which allows to identify the best qualities of the person [6, pp. 15-18] in the context of "a new social reality formation" [7, pp. 64-68] related to "public consciousness... of common cultural norms and values" [5, pp. 6-12].

Today the synthetic concept of the picture of the world attracts increasing attention of representatives of many sciences. The concepts of the scientific, artistic, linguistic picture 
of the world are being developed actively. Introducing the concept of the ethnic picture of the world, we get the opportunity to solve our own problems, based on the methodological potential of a new interdisciplinary scientific direction.

The cultural foundation of the ethnic group is structured. Its structure is closely related to its genesis and development. In turn, both the structure and the historical development of ethnic culture significantly affect the nature of its inclusion in the context of the spiritual life of modern ethnic groups. Highlighting the ethnic picture of the world, its historical types in the traditional and everyday, and professional culture of the people is an attempt to penetrate the internal structure of the socio-cultural memory of the people, to find out the laws of introducing new generations to the treasury of folk knowledge, skills, linguistic and other forms of world development.

There are also some traditional differences in labour education based on gender. So, for example, in preschool age, girls are more involved in different types of household chores. Their duty, as a rule, is to clean the house, including washing the floors, helping in cooking, washing the dishes and performing other works. Half of the surveyed women under the age of seven were involved in these kinds of work. Boys of this age had fewer permanent assignments, and they were generally less likely to be involved in housework. Nevertheless, half of the surveyed husbands in the surveyed families at that age performed different household duties. Preschool children were also entrusted with the care of younger brothers and sisters, the care of livestock, they also worked in the garden and in the field. As children grew older their duties became more complicated both in content and in physical activity. At the age of seven to twelve, almost one in four respondents could already perform all types of work in the farm, one in five worked in the field and in the garden, and one in ten was busy taking care of livestock. In this age group, the sexual age division of labour has also been preserved. The main occupation of girls is still various household chores related to everyday life. It can be assumed that at that time the children performed them more independently. Almost one in four girls worked in the garden or in the field, and a sixth of current adult women at that age did all kinds of farm work.

Thus, it can be argued that for this generation of people, childhood and work are inextricably linked. The continuation of traditions of labour education was also stimulated by objective necessity. The financial situation of most rural families requires significant labour efforts of all family members.

What changes are occurring in labour education of children in nuclear families? The living conditions of modern rural families are fundamentally different from those of peasants in the past. Without addressing the well-known social, economic, cultural and many other manifestations of these differences, let us briefly refer to those that are directly related to this study.

First of all, this concerns the content of the nature of the work itself, which is carried out in the field of public production. In society, labour is not just a means of ensuring life, but also a social need for most people. The modern family most often forms the orientation of children to a particular type of work, but the organized implementation of this is largely assumed by the system of social education, starting from education in a general educational institution and ending with higher educational institutions engaged in the development of individual abilities and inclinations of children.

The social policy of the state, naturally changing in historical times [3, pp. 45-49], is aimed at improving the domestic sphere of people's lifestyle, improving their material wellbeing and a number of other measures, leads to a fundamentally different organization of life, where many traditional work activities of children have no place.

In the vast majority of families, the widespread use of cultural and everyday education becomes the norm, which ultimately contributes to a radical change in the household sphere of the people's lifestyle. Naturally, in accordance with this, at present labour educa- 
tion of children in the family is fundamentally different from the traditional upbringing both in the areas of child labour participation and in the content and nature of the performed work [10].

At the same time, it can be said that the traditions of labour education of children persist quite firmly. In more than eighty per cent of families, for example, children have permanent household assignments. At the same time, it is important to note that parents in the vast majority of cases consider it necessary to involve children in the working life of the family, not only for the sake of an even distribution of household responsibilities among all family members. They believe that developing industriousness is a necessary factor in preparing children for their future family life. Every fifth father and every fourth mother in the upbringing of children attach importance to their preparation for their future family life, and teaching domestic work is considered as a way of this preparation. Not many parents believe that children in the family should not work due to age, workload in a general education institution and for other reasons.

Modern rural families have more favourable conditions for the transfer of labour traditions than urban ones. However, the labour activity of children at the present stage of social development is no longer as important as it was in the past, when their participation in peasant labour was urgently needed. Today, the continuation of this tradition is stimulated not so much by the need of the family for the work of children, but by the awareness of the need to form a conscious attitude among them to family-wide interests, the need for mutual assistance through labour [9, p.114]. This seems to explain the fact that in agriculture, children are most often busy with both or one of the parents. Their permanent assignments are rather of auxiliary nature.

The following conclusions can be drawn from the analysis of different types of lifestyle development in the context of ethnocultural traditions.

The first type of development of trends characterizing the traditions of labour education of children is determined by the socio-economic conditions of modern families, in particular the employment of parents in public production outside the home. Unlike the traditional peasant family, in which labour and the whole way of life were inextricably connected with the production of means of life in their economy and in which children were brought up by labour and for this particular labour, labour education in modern families has other goals. Today, labour education of children is mainly connected with the future profession and it is provided by various social institutions.

The second type is manifested in modern living conditions, where the forms and types of labour change, but the traditions of labour education are preserved. At the same time, it is advisable to intensify the propaganda of the best folk traditions of labour education of children, to maintain the current public opinion about labour in the field of public production and in the household as the main criterion for human value. There was a very lively perception of surviving traditions even in such fields as beliefs and knowledge. Two types of families are decisive for cultural integration: autochthons (owners) and returnees (new owners). So, from the very beginning, a group of returnees not only took up household, but also participated in the organization of various social institutions. In villages of this type there were numerous and very early intermarriages, which affected the reduction of conflicts.

The third type seems a bit different. Three similar regional groups had integrated very late. A certain percentage of borrowings from the local group concerned exclusively material culture, especially agricultural equipment and machinery. In the field of public culture, each group retained its own model, unification concerned only changes of traditional forms or their disappearance. Intermarriages, as an indicator of integration, have occurred only in recent years and only in the youth group.

In the fourth type, this process is diametrically different from those occurring in the 
first type. It is characterized by the presence of many groups originating from various regions of the country and the complete absence of a local group. It is impossible to talk about creating a single common model of traditional culture, each of the groups of families had its own model, gradually losing it or replacing it with a more urbanized one. It was also characteristic that differences were observed even in the field of material culture. Even more heterogeneity prevails in the field of public culture and beliefs. Only within the family, calendar customs and rites, the fulfilment of which required leaving the family for the village, were preserved very poorly. Family customs are limited exclusively to the family. Intermarriages between representatives of different groups have recently begun here, and among the youngest part of the population.

As you can see, the analysis reveals certain patterns. Wherever there were autochthonous families in the villages (complete, consisting of three generations), the integration process led to the unification of the existing model with the temporary preservation of traditional forms, most often characteristic for this group of families. The second group, the existence and magnitude of which affect the integration process, is the families of returnees. These families are also three generations old. Emphasizing the role of local families in the process of transforming and integrating the culture of the villages of these regions, the positive, although temporary, role of traditional culture should be emphasized. For migrant families who arrived in areas unfamiliar to them, a significant point in the first period of adaptation was that they met there a population that preserves, as well as them, cultural traditions (often similar). The similarity of cultural elements causes a favourable reaction. And despite the fact that the first period may not be free from conflicts (for example, bilingualism of the population and changed national consciousness), the processes of change in families went through cultural integration and assimilation, creating a model of family culture.

\section{Лumepamypa}

1. Бакланова О.А. Бакланов И.С. Современная российская социальность в контексте социального конструкционизма // Вопросы социальной теории. 2015. Т. 7. № 1-2. С. 168-177.

2. Говердовская Е.В. Особенности проектирования образовательного пространства высшей школы в поликультурном регионе // Экономические и гуманитарные исследования регионов. 2014. № 4. С. 7-10.

3. Гончаров В.Н. Социальный аспект религии в контексте развития первобытного общества // Гуманитарные и социально-экономические науки. 2016. № 2(87). C. 45-49.

4. Ерохин А.М. Религия и искусство в системе культуры // European Social Science Journal. 2014. № 7-2 (46). С. 9-12.

5. Колосова О.Ю. Духовная сфера: универсализм и самобытность // European Social Science Journal. 2012. № 11-2(27). С. 6-12.

6. Лобейко Ю.А. Социально-педагогический аспект активности личности в системе общественного развития // Экономические и гуманитарные исследования регионов. 2015. №1. С. 15-18.

7. Лукьянов Г.И. Трансформационные процессы в современном российском обществе как отражение динамики новой социальной реальности // Экономические и гуманитарные исследования регионов. 2017. № 4. С. 64-68.

8. Матяш Т.П., Несмеянов Е.Е. Православный тип культуры: идея и реальность // Гуманитарные и социально-экономические науки. 2015. № 3 (82). С. 39-44.

9. Мерклин В.А. Феномен "социального существа" в информационном обществе // Перспективы развития науки и образования. сборник научных трудов по ма- 
териалам XVIII международной научно-практической конференции. 2017. С. 113-115.

10. Kolosova O.Y., Goncharov V.N. Spiritual life of society: regional aspect // Научный альманах стран Причерноморья. 2015. № 4. http://science-almanac.ru

\section{References}

1. Baklanova O.A. Baklanov I.S. Sovremennaia rossiiskaia sotsialnost v kontekste sotsialnogo konstruktsionizma. Voprosy sotsialnoi teorii [Modern Russian sociality in the context of social constructionism. Questions of social theory]. 2015. V. 7. No. 12. pp. 168-177 (in Russian).

2. Goverdovskaya E.V. Osobennosti proektirovaniia obrazovatelnogo prostranstva vysshei shkoly v polikul'turnom regione. Ekonomicheskie i gumanitarnye issledovaniia regionov [Features of the design of the educational space of higher education in the multicultural region. Economic and humanitarian studies of the regions]. 2014. No. 4. pp. 7-10 (in Russian).

3. Goncharov V.N. Sotsialnyi aspekt religii v kontekste razvitiia pervobytnogo obshchestva. Gumanitarnye i sotsialno-ekonomicheskie nauki [Social aspect of religion in the context of the development of primitive society. Humanitarian and socioeconomic sciences]. 2016. No. 2(87). pp. 45-49 (in Russian).

4. Erokhin A.M. Religiia $\mathrm{i}$ iskusstvo v sisteme kultury [Religion and art in the system of culture]. European Social Science Journal. 2014. No. 7-2 (46). pp. 9-12 (in Russian).

5. Kolosova O.Yu. Dukhovnaia sfera: universalizm i samobytnost [Spiritual sphere: universalism and identity]. European Social Science Journal. 2012. No. 11-2(27). pp. 6-12 (in Russian).

6. Lobeiko Yu.A. Sotsialno-pedagogicheskii aspekt aktivnosti lichnosti v sisteme obshchestvennogo razvitiia. Ekonomicheskie i gumanitarnye issledovaniia regionov [Socio-pedagogical aspect of individual activity in the system of social development. Economic and humanitarian research of regions]. 2015. No. 1. pp. 15-18 (in Russian).

7. Lukyanov G.I. Transformatsionnye protsessy v sovremennom rossiiskom obshchestve kak otrazhenie dinamiki novoi sotsialnoi realnosti. Ekonomicheskie i gumanitarnye issledovaniia regionov. [Transformational processes in modern Russian society as a reflection of the dynamics of a new social reality. Economic and humanitarian research of regions]. 2017. No. 4. pp. 64-68 (in Russian).

8. Matyash T.P., Nesmeyanov E.E. Pravoslavnyi tip kultury: ideia i realnost. Gumanitarnye i sotsialno-ekonomicheskie nauki [Orthodox type of culture: idea and reality. Humanitarian and socio-economic sciences]. 2015. No. 3 (82). pp. 39-44 (in Russian).

9. Merklin V.A. Fenomen "sotsialnogo sushchestva" v informatsionnom obshchestve. Perspektivy razvitiia nauki i obrazovaniia. Sbornik nauchnykh trudov po materialam XVIII mezhdunarodnoi nauchno-prakticheskoi konferentsii. [The phenomenon of a "social being" in the information society. Prospects for the development of science 
and education. The collection of scientific works on the materials of the 18th international scientific and practical conference]. 2017. pp. 113-115 (in Russian).

10. Kolosova O.Y., Goncharov V.N. Spiritual life of society: regional aspect. Science almanac of Black Sea region countries. 2015. No. 4. Available at: http://sciencealmanac.ru 